\title{
Sexual activity of women - selected issues
}

\begin{abstract}
Introduction. Today, a lot of people's dreams are about attaining a sense of satisfaction from sexual life, staying sexually transmitted diseases (STD) - free or avoiding any infirmity and sexual violence. The overall change in people's attitudes toward sexuality and numerous hazards involved in risky behaviors calls for some scientific research focused on sexual life to be undertaken.

Aim. The aim of this study was to present selected issues concerning sexual activity of women.

Material and methods. 210 women aged 18 to 73 years with a diagnosis of a disease of the reproductive organ. The participants were being hospitalized at one of four gynecological departments. A diagnostic survey using the author's own questionnaire was performed.

Results. On average, the respondents had sex for the first time at the age range of 19 to 22 (45.7\%). Most respondents have had one partner during their life (67.0\%). Some 39.3\% of the respondents admitted to have sex on a regular basis.

Conclusions. 1. Early sexual onset was mostly preferred by both younger women and respondents reporting the lowest level of education. 2. Irregular and sporadic sexual contacts were common for women holding a primary or vocational education degree. 3. It is recommended that selected characteristics of sexual activity of women, particularly regarding the number of partners and sexual initiation, were subject to periodic epidemiological analysis as the potential health risk factors.
\end{abstract}

Keywords: women, sexuality, health.

DOI: $10.1515 /$ pjph-2015-0039

\section{INTRODUCTION}

Sexual relationships are an important part of life. There are numerous customs and norms specific for various cultures and religions around the world and they have evolved over centuries [1]. Although the traditions concerning sexual contact have a rich history, the society started to show increased interest in human sexuality only at the turn of the nineteenth and twentieth century $[1,2]$. There has been some significant progress in the field of sex research, both looking at sexuality itself and diagnosing or treating sexual disorders [2,3]. Currently, it has become so advanced a field of research, particularly in terms of imaging methods and the methodology of clinical and experimental studies that researchers are pondering over distinguishing sexual medicine from sexology. Moreover, some new subspecialties have emerged recently, like sexology of the developmental age, old age, judicial sexology and sexual endocrinology [2]. Sexual health has become a subject of specialist research, implying that there is a clear relationship between having a satisfactory sexual life and the quality of life of women and men. Due to the ongoing changes in the attitudes of the population towards their own sexuality and the presence of numerous threats, stemming from risky behaviors, there is a need to undertake research on sexual life.

\section{AIM}

The aim of the study was to present selected issues of women's sexual activity.

\section{MATERIAL AND METHODS}

The study group were patients of four gynecological departments. A group of female inpatients hospitalized due to a disease of their reproductive organ (the author has excluded pregnant women and those who had experienced a miscarriage). The patients in the study was anonymous and voluntary. The study was based on a diagnostic survey using a questionnaire of the authors' own making.

210 women aged 18 to 73 years (with the mean age 45.5 ), inpatients of four gynecological wards were subjects of the study. The four age classes were as follows: 1. under 35 years of age ( $\leq 35$ years $)-21.9 \% ; 2$. 36-45 years $-24.8 \%$; 3. $46-55$ years $-37.6 \%$ and 4 . above 56 years ( $\geq 56$ years) $15.7 \%$ of women. Most participants had earned a secondary education degree $(52.4 \%)$. The number of women holding a higher education degree was identical with the number of women holding a degree in primary and vocational education and it was $23.8 \%$. The respondents were also varied by their place of residence: residents of rural areas $(36.7 \%$ 
of women), residents of cities with more than 100.000 inhabitants ( $>100$ thousand inhabitants) $-35.7 \%$ of patients and the respondents living in cities up to 100,000 inhabitants ( $\leq 100$ thousand inhabitants) $-27.6 \%$.

Statistical analyses were performed using SPSS V.12 pl statistical software. A $\chi^{2}$ test was used for assessing the significance of differences for categorical data. Values of $\mathrm{p}<0.05$ were considered statistically significant.

\section{RESULTS}

The average ages at the first sexual intercourse ranged from 19 to 22 for some $45.7 \%$ of the surveyed group. The women older than 56 years constituted the largest group. For some $37.6 \%$ of the respondents, the age at first sex was before reaching maturity ( $\leq 18$ years). Such patterns can be noticed mostly among respondents with primary and vocational education, as well as the youngest respondents ( $\leq 35$ years), with the lowest age of onset 15 years. Also, the age at first sex for some $14.8 \%$ was 23 or more ( $\geq 23$ years). This group was most strongly represented by patients holding a higher education degree. The smallest group were women who had yet to begin their sexual life $(1.9 \%)$. There was no relationship between one's place of residence and the age at onset. Some huge differences between patients appeared when looking at age $(p<0.05)$ and level of education $(p<0.001)$ - Table 1 .

Sexually active women were asked to disclose the number of their sexual partners. Most women had had one partner only $(67.0 \%)$, whilst some $18.0 \%$ of them admitted to having two sexual partners, and $15.0 \%$ of them had three and more partners. Such factors as age, education and place of residence did not have any effect over this - Table 2 .

Among the respondents who experienced a sexual initiation, most women, i.e. $52.9 \%$ did not keep up a regular sex life. This group mainly consisted of patients reporting rather low levels of education (e.g. primary, vocational). Some $39.3 \%$, most of which were women with higher education, claimed that they had a regular sex life. Also, 7.8\% of patients reported to have occasional sexual relations. There were no differences in terms of share of respondents by age and place of residence, significant differences were among women in division into categories of education $(p<0.01)-$ Table 3.

TABLE 1. Age at first sex - by the patients' age, education and place of residence.

\begin{tabular}{|c|c|c|c|c|c|c|c|c|c|c|c|c|}
\hline \multirow{2}{*}{\multicolumn{2}{|c|}{$\begin{array}{l}\text { Age of women } \\
\text { (in years): } \\
\leq 35\end{array}$}} & \multicolumn{4}{|c|}{ Age groups in years } & \multicolumn{3}{|c|}{ Education } & \multicolumn{3}{|c|}{ Place of residence } & \multirow[b]{2}{*}{ Total } \\
\hline & & $36-45$ & $46-55$ & $\geq 56$ & $\begin{array}{c}\text { primary } \\
\text { and } \\
\text { vocational }\end{array}$ & $\begin{array}{l}\text { secondary } \\
\text { and post- } \\
\text { secondary }\end{array}$ & $\begin{array}{l}\text { higher incl } \\
\text { bachelor's } \\
\text { degree }\end{array}$ & $\begin{array}{l}\text { rural } \\
\text { areas }\end{array}$ & $\begin{array}{r}\text { town } \leq 100 \\
\text { thous inhab. }\end{array}$ & $\begin{array}{c}\text { city }>100 \\
\text { thous inhab. }\end{array}$ & & \\
\hline \multirow{2}{*}{$\begin{array}{l}\text { had no } \\
\text { sexual life }\end{array}$} & $\mathrm{N}$ & 4 & - & - & - & 1 & 3 & - & 3 & 1 & - & 4 \\
\hline & $\%$ & 8.7 & - & - & - & 2.0 & 2.7 & - & 3.9 & 1.7 & - & 1.9 \\
\hline \multirow{2}{*}{$\leq 18$} & $\mathrm{~N}$ & 21 & 19 & 30 & 9 & 26 & 43 & 10 & 32 & 20 & 27 & 79 \\
\hline & $\%$ & 45.7 & 36.5 & 38.0 & 27.3 & 52.0 & 39.1 & 20.0 & 41.6 & 34.5 & 36.0 & 37.6 \\
\hline \multirow{2}{*}{$19-22$} & $\mathrm{~N}$ & 18 & 23 & 35 & 20 & 20 & 54 & 22 & 33 & 29 & 34 & 96 \\
\hline & $\%$ & 39.1 & 44.2 & 44.3 & 60.6 & 40.0 & 49.1 & 44.0 & 42.9 & 50.0 & 45.3 & 45.7 \\
\hline \multirow{2}{*}{$\geq 23$} & $\mathrm{~N}$ & 3 & 10 & 14 & 4 & 3 & 10 & 18 & 9 & 8 & 14 & 31 \\
\hline & $\%$ & 6.5 & 19.2 & 17.7 & 12.1 & 6.0 & 9.1 & 36.0 & 11.7 & 13.8 & 18.7 & 14.8 \\
\hline \multirow{3}{*}{ Total } & $\mathrm{N}$ & 46 & 52 & 79 & 33 & 50 & 110 & 50 & 77 & 58 & 75 & 210 \\
\hline & $\%$ & 100.0 & 100.0 & 100.0 & 100.0 & 100.0 & 100.0 & 100.0 & 100.0 & 100.0 & 100.0 & 100.0 \\
\hline & \multicolumn{5}{|c|}{$\begin{array}{c}\mathrm{Chi}^{2}=21.55 \\
\mathrm{DF}=9 \\
\mathrm{p}<0.05\end{array}$} & & $\begin{array}{c}\mathrm{Chi}^{2}=29.22 \\
\mathrm{DF}=6 \\
\mathrm{p}<0.001\end{array}$ & & \multicolumn{3}{|c|}{$\begin{array}{c}\mathrm{Chi}^{2}=5.24 \\
\mathrm{DF}=6 \\
\text { p-n.i. }\end{array}$} & \\
\hline
\end{tabular}

TABLE 2. Number of sexual partners in a lifetime - by age, education and place of residence.

\begin{tabular}{|c|c|c|c|c|c|c|c|c|c|c|c|c|}
\hline \multirow{2}{*}{\multicolumn{2}{|c|}{$\begin{array}{c}\text { Number of } \\
\text { sexual } \\
\text { partners }\end{array}$}} & \multicolumn{4}{|c|}{ Age groups in years } & \multicolumn{3}{|c|}{ Education } & \multicolumn{3}{|c|}{ Place of residence } & \multirow[b]{2}{*}{ Total } \\
\hline & & $\leq 35$ & $36-45$ & $46-55$ & $\geq 56$ & $\begin{array}{c}\text { primary } \\
\text { and } \\
\text { vocational }\end{array}$ & $\begin{array}{l}\text { secondary } \\
\text { and post- } \\
\text { secondary }\end{array}$ & $\begin{array}{c}\text { higher } \\
\text { including } \\
\text { bachelor's } \\
\text { degree }\end{array}$ & $\begin{array}{l}\text { rural } \\
\text { areas }\end{array}$ & $\begin{array}{c}\text { town } \leq 100 \\
\text { thousand } \\
\text { inhabitants }\end{array}$ & $\begin{array}{c}\text { city }>100 \\
\text { thousand } \\
\text { inhabitants }\end{array}$ & \\
\hline \multirow{2}{*}{ one } & $\mathrm{N}$ & 23 & 33 & 59 & 23 & 33 & 75 & 30 & 56 & 33 & 49 & 138 \\
\hline & $\%$ & 54.8 & 63.5 & 74.7 & 69.7 & 67.3 & 70.1 & 60.0 & 75.7 & 57.9 & 65.3 & 67.0 \\
\hline \multirow{2}{*}{ two } & $\mathrm{N}$ & 11 & 10 & 11 & 5 & 8 & 19 & 10 & 9 & 13 & 15 & 37 \\
\hline & $\%$ & 26.2 & 19.2 & 13.9 & 15.2 & 16.3 & 17.8 & 20.0 & 12.2 & 22.8 & 20.0 & 18.0 \\
\hline \multirow{2}{*}{$\begin{array}{l}\text { three } \\
\text { and more }\end{array}$} & $\mathrm{N}$ & 8 & 9 & 9 & 5 & 8 & 13 & 10 & 9 & 11 & 11 & 31 \\
\hline & & 19.0 & 17.3 & 11.4 & 15.2 & 16.3 & 12.1 & 20.0 & 12.2 & 19.3 & 14.7 & 15.0 \\
\hline \multirow{3}{*}{ Total } & $\mathrm{N}$ & 42 & 52 & 79 & 33 & 49 & 107 & 50 & 74 & 57 & 75 & 206 \\
\hline & $\%$ & 100.0 & 100.0 & 100.0 & 100.0 & 100.0 & 100.0 & 100.0 & 100.0 & 100.0 & 100.0 & 100.0 \\
\hline & & & $\begin{array}{c}\mathrm{Chi}^{2}=5 \\
\mathrm{DF}= \\
\text { p-n.i }\end{array}$ & & & & $\begin{array}{c}\mathrm{Chi}^{2}=2.18 \\
\mathrm{DF}=4 \\
\text { p-n.i. }\end{array}$ & & & $\begin{aligned} & \mathrm{Chi}^{2}=4 . \\
& \mathrm{DF}=4 \\
& \text { p-n.i. }\end{aligned}$ & & \\
\hline
\end{tabular}


TABLE 3. Sexual intercourse frequency by age, education and place of residence.

\begin{tabular}{|c|c|c|c|c|c|c|c|c|c|c|c|c|}
\hline \multirow{2}{*}{\multicolumn{2}{|c|}{$\begin{array}{c}\text { Regularity } \\
\text { of sexual } \\
\text { intercourses }\end{array}$}} & \multicolumn{4}{|c|}{ Age groups in years } & \multicolumn{3}{|c|}{ Education } & \multicolumn{3}{|c|}{ Place of residence } & \multirow[b]{2}{*}{ Total } \\
\hline & & $\leq 35$ & $36-45$ & $46-55$ & $\geq 56$ & $\begin{array}{c}\text { primary } \\
\text { and } \\
\text { vocational }\end{array}$ & $\begin{array}{l}\text { secondary } \\
\text { and post- } \\
\text { secondary }\end{array}$ & $\begin{array}{c}\text { higher } \\
\text { including } \\
\text { bachelor's } \\
\text { degree }\end{array}$ & $\begin{array}{l}\text { rural } \\
\text { areas }\end{array}$ & $\begin{array}{c}\text { town } \leq 100 \\
\text { thousand } \\
\text { inhabitants }\end{array}$ & $\begin{array}{c}\text { city }>100 \\
\text { thousand } \\
\text { inhabitants }\end{array}$ & \\
\hline \multirow{2}{*}{ regular } & $\mathrm{N}$ & 18 & 20 & 29 & 14 & 9 & 43 & 29 & 24 & 22 & 35 & 81 \\
\hline & $\%$ & 42.9 & 38.5 & 36.7 & 42.4 & 18.4 & 40.2 & 58.0 & 32.4 & 38.6 & 46.7 & 39.3 \\
\hline \multirow{2}{*}{ irregular } & $\mathrm{N}$ & 20 & 25 & 46 & 18 & 34 & 59 & 16 & 43 & 29 & 37 & 109 \\
\hline & $\%$ & 47.6 & 48.1 & 58.2 & 54.5 & 69.4 & 55.1 & 32.0 & 58.1 & 50.9 & 49.3 & 52.9 \\
\hline \multirow{2}{*}{ occasional } & $\mathrm{N}$ & 4 & 7 & 4 & 1 & 6 & 5 & 5 & 7 & 6 & 3 & 16 \\
\hline & & 9.5 & 13.5 & 5.1 & 3.0 & 12.2 & 4.7 & 10.0 & 9.5 & 10.5 & 4.0 & 7.8 \\
\hline \multirow{3}{*}{ Total } & $\mathrm{N}$ & 42 & 52 & 79 & 33 & 49 & 107 & 50 & 74 & 57 & 75 & 206 \\
\hline & $\%$ & 100.0 & 100.0 & 100.0 & 100.0 & 100.0 & 100.0 & 100.0 & 100.0 & 100.0 & 100.0 & 100.0 \\
\hline & & & $\begin{array}{c}\mathrm{Chi}^{2}=5 \\
\mathrm{DF}= \\
\mathrm{p}-\mathrm{n} .\end{array}$ & & & & $\begin{array}{c}\mathrm{Chi}^{2}=19.58 \\
\mathrm{DF}=4 \\
\mathrm{p}<0.01\end{array}$ & & & $\begin{aligned} & \mathrm{Chi}^{2}=4 . \\
& \mathrm{DF}=4 \\
& \text { p-n.i. }\end{aligned}$ & & \\
\hline
\end{tabular}

\section{DISCUSSION}

The beginning of sex life is an important moment for every human being. It should take place after the individual's reaching of a biological, psychological, sexual and social maturity [4]. It is hardly possible to determine the actual moment when all of these criteria have been fulfilled, since reaching maturity happens at different points in life and those processes differ for boys and girls [4-6]. Researchers believe that "the limits of the standards of puberty for girls are set between 8-16 years of age, and for boys between 9-17 years" $[5,6]$. However, men tend to experience full sexual satisfaction later in life, since women have the ability to experience an orgasm, between $18-25$ years of age $[5,6]$. Some laws related to sexual freedom and morality are an important aspect here as well. Young people tend to have a rather liberal approach toward sexual activity. In Poland, the age of consent is 15 years, which means that committing any sexual acts with a younger person is a criminal offense leading to imprisonment [7]. This means, the youth older than 15 years can start to be sexually active, without the risk of facing legal consequences.

The author's own research shows that most respondents become sexually active around the age of 19-22 years or earlier. Overall, they do so before reaching adulthood ( $\leq 18$ years) $-83.3 \%$. Nowosielski K. et al. obtained similar results in their studies of sexuality of young adults in Silesian province. Here, respondents had their first sexual intercourse at an average age of 18.8 [4]. However, the authors of numerous reports indicate that the age of sexual initiation lowers $[4,8,9]$, the women later than men decide to start sexual life [4]. In the studies conducted among students (girls and boys) of high schools of Mazowieckie and Silesian Provinces it was found that the average age of initiation was 16.5 ( \pm 1.5 years). Some $32.35 \%$ declared they had sex before 15 [9]. Also Jarząbek-Bielecka G. et al. showed decrease in the age of initiation of sexual intercourse, from 19.11 years for women born in the years 1975-1984 to 16.35 years for women born in 1985-1995. Also, the percentage of people who experienced sexual initiation before the age of 15 increased by $8.2 \%$ [8]. Among the factors that are conductive to earlier sexual initiation are: the availability of significant financial resources for their own expenses, frequent truancy, too intense socialization with their peers, the use of psychoactive substances, poor school performance, good housing conditions, living in the dormitory and cigarette smoking [4]. The data presented in the literature show that in Poland, about $1 \%$ of people declare sexual initiation under the age of 13 [4].

Due to a huge variety of risks that engaging in sexual activity poses, adhering to the rules of safe sex can have a major impact on human health. The high prevalence of medical, social and cultural problems, being the consequences of risky behavior and/or disregard for the basic principles of personal hygiene and preventive care receive most attention from researchers. For instance, Valentina B. points to numerous risks associated with the start of sexual life [10] and this does not only pertain to young people. A study by Kowalczyk R. et al., has shown that there are some disturbing tendencies in Poland, like an increase in the number of HIV infections among women, late detection of new cases, the lack of reference of the risk of infection to oneself and rising costs related to the prevention and treatment of infected persons [11]. It seems that having sexual intercourses with one partner only (confirmed by $67.0 \%$ of women) is a reasonable approach to prevent the spread of sexually transmitted diseases. However, there is a risk that some patients failed to disclose real answers and concealed the actual number of sexual partners. Still, the issues concerning sexual activity are considered to be rather embarrassing and preferably kept secret.

The social attitude toward sexuality has changed over the years. Lew-Starowicz believes that the new approach is characterized by: the development of a partnership model in male-female relationships, becoming more open toward sex, separating sex from procreation and the treatment of successful sex life as an important factor of promoting health and quality of life [2]. However, the data published in the literature may give rise to considerable concern about the sexual health of women. According to Przybylski M. and Spaczyński M., sexual dysfunction can affect $20-40 \%$ of the female population, one third of women show a lack of interest in sex, while $20 \%$ of women do not find sexual life enjoyable [12]. According to Lew-Starowicz Z., sexual 
arousal disorder affects some $20 \%$ of the female population [2]. Also Knypl K., a participant of the Congress of the International Society for the Study of Women's Sexual Health, cited test results, according to which as many as $63.5 \%$ of respondents expressed dissatisfaction with their sexual life [13]. Some interesting findings were also received by Jankowiak B. In light of these, only $45.5 \%$ of women have experienced an orgasm through sexual contact and $5.8 \%$ of women have never experienced an orgasm [14]. Another author, Wróbel B., said that almost half of the surveyed women in both groups (declaring successful and unsuccessful sexual life) had intercourse against their will, and believed that a husband has the right to rape his wife [15]. Yet, the high sense of sexual attraction favors high level of satisfaction in this area of life. The authors' own research shows that the majority of respondents $(60.7 \%)$ had irregular or occasional sexual contacts. These findings show how many respondents derive joy from their sex lives.

To conclude, it must be stated that sexual activity is an important aspect of human life. Currently, such factors as the overall quality of life, a positive personal development, good communication and love are identified with sexual health. The World Health Organization has counted sexual rights along with other rights of an individual, which demonstrates the huge importance of this sphere of life. Having a satisfying sexual life, staying free from diseases, impotence and sexual violence is one of the most important aspirations of a modern human being [2].

\section{CONCLUSIONS}

1. There is a link between low levels of education and an early sexual initiation, as patients with poor education reported the youngest age at sexual initiation (as well as young women.)

2. Irregular or occasional sexual contacts were kept mostly by women with primary and vocational education.

3 . It is recommended that selected characteristics of the sexual activity of women, particularly those pertaining to the number of partners and the age of sexual initiation, are identified as potential health risks and become subject to a periodic epidemiological analysis.

\section{REFERENCES}

1. Genstwa M, Mania E, Nowak A, Jarząbek-Boelecka G. Seksualność, kobiecość w kulturach i religiach świata. Ginekol Prakt. 2009;17(4):4152.

2. Lew-Starowicz Z. Nowe kierunki rozwoju badań nad seksualnością kobiet i mężczyzn. Przew Lek. 2008;1:37-9.

3. Radomski D. Od poznania się do seksualnej satysfakcji, czyli biologiczne mechanizmy seksualności człowieka. Seksuol Pol. 2007;5(1):18-24.

4. Nowosielski K, Drosdzol A, Skrzypulec V, et al. Seksualność młodych dorosłych województwa śląskiego. Ginekol Prakt. 2005;13(2):32-9.

5. Sowińska-Przepiera E, Jarząbek G. Zdrowie seksualne w aspekcie ginekologii wieku rozwojowego. Ginekol Prakt. 2007;15(2):39-42.

6. Jarząbek G, Sowińska-Przepiera E, Ochmańska K, et al. Biomechanizmy seksualności dziewcząt. Klin Pediatr. 2009;17(2):269-74.

7. Ustawa z dnia 6 czerwca 1997r. Kodeks Karny. Dz.U. z 1997 nr 88, poz.553 z późniejszymi zmianami, art. 200.

8. Jarząbek-Bielecka G, Durda M, Kaczmarek M. Inicjacja a aktywność seksualna dziewcząt i kobiet. Prz Seksuol. 2011;7(3):14-6.

9. Kościołek A, Cuber T, Girzelska J. Zachowania seksualne wśród młodzieży ponagimnazjalnej, a system moralności seksualnej. Zdr Publ. 2011;121(1):16-21.

10. Kowalczyk R, Folwarczny W, Szpak R, Skrzypulec V. Zaburzenia psychoseksualne osób zakażonych wirusem HIV. Seksuol Pol. 2009;7(2):52-8.

11. Przybylski M, Spaczyński M. Obniżenie popędu seksualnego u kobiet. Ginekol Pol. 2009;80(7):518-22.

12. Knypl K. Zdrowie seksualne kobiet. Sprawozdanie z kongresu International Society for the Study of Women's Sexual Health, Lizbona - 2006. Przew Lek. 2006;3:88-9.

13. Jankowiak B. Aktywność seksualna współczesnych nauczycieli. Wyniki badań własnych. Seksuol Pol. 2008;6(2):64-76.

14. Wróbel B. Wyniki badania wybranych cech seksualności starszych kobiet w związku małżeńskim. Ginekol Pol. 2008;79(2):99-107.

15. Baltag V. Advancing reproductive health of Young people In the European Region. Med Wieku Rozw. 2008;12(2):521-30.

\section{Corresponding author}

Aleksandra Słopiecka

Wydział Lekarski i Nauk o Zdrowiu, Uniwersytet Jana Kochanowskiego w Kielcach

19 IX Wieków Kielc Ave, 25-317 Kielce

E-mail: aleksaonet@op.pl 